\title{
Cabezas de playa: los inicios del movimiento obrero en Entre Ríos, Argentina, 1893-1916
}

\author{
Beachheads: the beginnings of the labor movement in Entre Ríos, \\ Argentina, 1893-1916
}

\section{Rodolfo Leyes*}

Resumen: La historia de la clase obrera se ha abierto como un campo historiográfico propio en los estudios históricos argentinos. Este prolífico desarrollo, que abarcó la historia de sus organizaciones, luchas y disputas políticas-ideológicas, contrasta con la falta de estudios sobre el interior del país. No porque no existan, sino porque existe en el interior del país un terreno inexplorado hasta en sus aspectos más básicos, desentonando con el grado de desarrollo de la historiografía sobre Buenos Aires. El presente trabajo reconstruye una de aquellas faltantes, los inicios del movimiento obrero en Entre Ríos. Para explicar el desarrollo particular debemos reconstruir parcialmente el incremento de la economía capitalista asociada a la actividad agrícola y al abasto local, luego se mostrará el avance de las primeras organizaciones obreras impulsadas por socialistas y anarquistas para finalizar con un repaso de las principales luchas económicas del periodo.

Palabras clave: Movimiento obrero; Entre Ríos, Argentina; Conflictos obreros.

Abstract: The history of the working class has opened as its own historiographical field in Argentine historical studies. This prolific development, which encompassed the history of their organizations, struggles and political-ideological disputes, contrasts with the lack of studies on the interior of the country. Not because there are none, but because there is an unexplored terrain in the country's interior even in its most basic aspects, contrasting with the degree of development of the historiography on Buenos Aires. This work reconstructs one of those missing, the beginnings of the labor movement in Entre Ríos. To explain the

\footnotetext{
* Doctor en Historia, Facultad de Filosofía y Letras, Universidad de Buenos Aires (2018). Docente en la Facultad de Humanidades, Artes y Ciencia Sociales de la Universidad Autónoma de Entre Ríos. E-mail: rodolfoleyes@ yahoo.com.ar. ORCID: https://orcid.org/0000-0001-7112-7832.
} 
particular development we must partially reconstruct the increase in the capitalist economy associated with agricultural activity and local supply, then the progress of the first workers' organizations promoted by socialists and anarchists will be shown, to finish with a review of the main economic struggles of the period.

Keywords: Labor movement; Entre Ríos, Argentina; Workers' struggles.

\section{Introducción}

A PROVINCIA DE ENTRE Ríos, al igual que otros espacios de la pampa húmeda argentina, disfrutó de un crecimiento sin precedentes a partir de la década de 1880-90. Esta expansión, basado en una ampliación de la agricultura moderna y el crecimiento de industrias de exportación y abasto local, generó y ocupó a un crecido número de trabajadores asalariados. Resultado de aquellas actividades económica fue que, desde los últimos años de la década de 1890, comenzaron a producirse manifestaciones de conflicto laboral y a tomar forma las organizaciones obreras, encabezadas por anarquistas y socialistas, en diversas localidades.

Pero fue en el cambio de siglo cuando se reconoce el nacimiento del movimiento obrero en la provincia, ya no como destellos aislados de un sujeto social en formación, sino como un movimiento estable. La continuidad de las organizaciones nos habla de núcleos obreros permanentes, pero también de una experiencia acumulada. En este periodo veremos también como la clase obrera entrerriana comienza a organizarse "de afuera para adentro", es decir, a partir de la acción de militantes que visitaron la provincia con el objetivo de organizar o apuntalar las organizaciones que nacían espontáneamente, por otra parte, es un movimiento centrado en las ciudades-puerto más importantes de la provincia.

El nacimiento de estas organizaciones coincide con las corrientes ideológicas del movimiento obrero de la época, pero comienza a delimitarse un rasgo característico y persistente del movimiento obrero entrerriano, que es la división entre las costas del río Uruguay y la del Paraná. Mientras en las ciudades del río Paraná, se destacaba la militancia anarquista, en las ciudades sobre la costa del río Uruguay, fueron espacio de militancia socialista o sindicalista revolucionaria. Esta delimitación geográfica-ideológica arraigó las relaciones políticas entre los núcleos obreros locales y el movimiento obrero del resto del país.

La clase obrera y su movimiento reivindicatorio son actores de indudable importancia en la historia argentina. La militancia de socialistas y anarquistas en las últimas décadas del siglo XIX contrastaba como una disidencia a la hegemonía de la burguesía agro-ganadera. La aparición del movimiento obrero organizado fue percibida como un fenómeno que a priori no tenía razón de ser. Esta aparente "disonancia" social fue objeto de estudios estatales, entre los que se destacó la obra de Bialet Massé. ${ }^{1}$

$\overline{1}$ BIALET MASSÉ, Juan. Informe sobre el estado de la clase obrera. Buenos Aires: Hyspamerica Ediciones, 1985. 
Pronto, pero con particular fuerza desde la década del treinta y del cuarenta, comenzaron a ser publicados estudios y memorias sobre el movimiento obrero argentino. Estos trabajos de historiadores militantes, por ser muchas veces ellos mismos actores de sus propios relatos, tenían por fin destacar la historia de la clase obrera previa al peronismo y demostrar que sus corrientes habían forjado el movimiento obrero que finalmente, y en apariencia de modo irremediable, eran engullidos por aquel movimiento. En los trabajos de autores socialistas, anarquistas y sindicalistas afloró el peso del proletariado del interior, situación que se explica por la metodología de reconstrucción de estos trabajos, centrados en el análisis de las prensas obreras, las actas de los congresos y volantes varios. En particular el trabajo de Marotta destacó al proletariado organizado de la provincia de Entre Ríos, hecho que resulta lógico siendo esta provincia un bastión sindicalista. ${ }^{2}$

En las décadas siguientes, la historiografía sobre el movimiento obrero se profesionalizó y comenzó a ser objeto de estudio para sociólogos e historiadores. Nuevamente los debates que dinamizaban las investigaciones eran las explicaciones sobre el origen del peronismo, el peso de una supuesta vieja clase obrera en contraposición a una nueva clase obrera y el lugar de los migrantes internos. ${ }^{3}$ En este punto del debate, solo Halperin Donghi y Korzeniewicz ${ }^{4}$ señalaron la militancia en el interior argentino para demostrar la falsedad del presupuesto sobre masas obreras desprovistas de experiencias. Ninguno de los dos autores analizó el caso entrerriano.

En las décadas del ochenta y noventa las discusiones sobre el peronismo tendieron a estancarse en torno al paradigma "continuista-heterodoxo"5 y se volvió a un estudio de aspectos no investigados, como el origen de las primeras organizaciones, el lugar del anarquismo en aquellos sindicatos, el trabajo en las fábricas, el lugar de las mujeres, la relación con el Estado, ${ }^{6}$ y por primera vez, ya en los noventa, comenzó aparecer una historiografía que se preocupaba por la pampa húmeda y particularmente por Entre Ríos. ${ }^{7}$

2 ABAD DE SANTILLÁN, Diego. La FORA, Ideología y trayectoria del movimiento obrero revolucionario en la Argentina. Buenos Aires: Anarres, 2005; MAROTTA, Sebastián. El movimiento sindical argentino, su génesis y su desarrollo. Buenos Aires: Lacio, 1961; ODDONE, Jacinto. Gremialismo proletario argentino. Buenos Aires: Libera, 1975.

3 GERMANI, Gino. Política y sociedad en una época de transición. Buenos Aires: Paidos, 1962; DI TELLA, Guido. El sistema político argentino y la clase obrera. Buenos Aires: EUDEBA, 1964; MURMIS, Miguel; PORTANTIERO, Juan Carlos. Estudios sobre los orígenes del peronismo. Buenos Aires: Siglo XXI Editores, 2006.

4 HALPERÍN DONGHI, Tulio. Algunas observaciones sobre Germani, el surgimiento del peronismo y los migrantes internos. Desarrollo Económico, Buenos Aires, n. 56, p. 765-781, 1975; KORZENIEWICZ, Roberto. Las migraciones internas en los orígenes del peronismo: tres observaciones empíricas. Ciclos, Buenos Aires, a. III, v. III, n. 5, p. 113-126, $2^{\circ}$ semestre, 1993.

5 JAMES, Daniel. Los orígenes del peronismo y la tarea del historiador. Revista Archivos de historia del movimiento obrero y la izquierda, Buenos Aires, a. II, n. 3, p. 131-147, sep. 2013.

6 PANETTIERI, José. Los trabajadores. Buenos Aires: CEAL, 1982; PANETTIERI, José. Primeras leyes obreras. Buenos Aires: CEAL, 1984; FALCÓN, Ricardo. EI mundo del trabajo urbano (1890-1914). Buenos Aires: CEAL, 1986; KORZENIEWICZ, Roberto. Labor unrest in Argentina, 1887-1907. Latin American Research Review, v. 24, n. 3, p. 71-98, 1989; SABATO, Hilda; ROMERO, Luis Alberto. Los trabajadores de Buenos Aires. La experiencia del mercado: 1850-1880. Buenos Aires: Sudamericana, 1992; ZARAGOZA, Gonzalo. Anarquismo argentino (1876-1902). Madrid: Ediciones de la Torre, 1996; SURIANO, Juan. Anarquistas: Cultura y política libertaria en Buenos Aires, 1890-1910. Buenos Aires: Manantial, 2001.

7 ARNAIZ, María del Carmen. Un oasis en el desierto: La Unión Obrera Departamental de Concepción del Uruguay 1920-1943. In: DI TELLA, Torcuato (comp.). Sindicatos como los de antes... Buenos Aires: Biblos, 1993. p. 81-115; ARNAIZ, María del Carmen. Aires libertarios: la Federación Obrera Comarcal Entrerriana, 
Estos trabajos, a priori cubrieron la vacancia absoluta, pero no respondieron todas las preguntas. Por empezar, por lo acotado de su recorte cronológico comprendido entre 19201930, no observaron los orígenes de la organización; en segundo lugar, la mirada centrada en el espacio agrícola, con las dificultades de delimitar aquel espacio, dejó afuera a los núcleos urbanos de la provincia, y en tercer lugar, la mirada estaba centrada en la conflictividad y no en la organización. Investigaciones producidas en las últimas décadas han mostrado los inicios de las luchas obreras a mediados del siglo $\mathrm{XIX}^{8}$ y se han reconstruido parcialmente huelgas aisladas, ${ }^{9} \mathrm{y}$ experiencias culturales vinculadas al anarquismo local. Todo esto muestra un incremento de los estudios particulares sobre la provincia de Entre Ríos, pero se siguen presentando cuadros parciales.

El objetivo del presente trabajo es exponer los inicios del movimiento obrero en Entre Ríos, territorio comprendido dentro de la región más desarrollada de la Argentina, pero en una situación de cuasi-aislamiento por su condición mesopotámica. La elección del territorio se justifica por la vacancia aún existente en torno a los orígenes decimonónicos, pero también porque rompe con los estudios que centran el análisis en el eje de grandes ciudades pampeanas. En este caso, una provincia pampeana periférica, nos puede enseñar las dificultades de crear un tipo de organismo social novedoso para aquella sociedad, con el cual debió tratar el estado y proyecta, indirectamente, una luz sobre las condiciones materiales de los trabajadores. El recorte temporal se estableció a partir de la creación del primer núcleo de militantes socialistas conocido y se cierra con la elección de Hipólito Yrigoyen, presidente de la nación que modificó la relación entre el estado y el movimiento obrero.

Para la reconstrucción nos hemos valido de una gran variedad de fuentes. Se destaca el uso de periódicos obreros de la época, prensas comerciales de diversas localidades de la provincia, memorias de contemporáneos y fuentes estatales del Boletín del Departamento Nacional del Trabajo. Por último hemos trabajado con fuentes inéditas como las actas de la Unión General de los Trabajadores de la ciudad de Buenos Aires y correspondencia del Partido Socialista de Concepción del Uruguay.

1920-1940. Anuario IEHS, Tandil, n. 6, p. 283-300, 1991; SARTELLI, Eduardo. Sindicatos obreros-rurales en la región pampeana, 1900-1922. In: ANSALDI, Waldo (comp.). Conflictos obreros rurales pampeanos, 1900-1937. Tomo III. Buenos Aires: CEAL 1993; ASCOLANI, Adrián. El sindicalismo rural en la Argentina. Bernal: Universidad Nacional de Quilmes, 2009.

8 LEYES, Rodolfo. Destellos de un nuevo sujeto: Los conflictos obreros en los saladeros y la formación de la clase obrera entrerriana (1854-1868). Mundo Agrario, UNLP, v. 15, n. 30, diciembre 2014. Disponible en: http://sedici.unlp.edu.ar/handle/10915/46216. Acceso el: 13 ago. 2020.

9 SACK, José. Se enciende la lucha. Representaciones de los obreros en la ciudad de Paraná. El caso de la huelga de la Fábrica de Fósforos en 1906. Tesina de seminario de Síntesis, Profesorado en Historia, Universidad Autónoma de Entre Ríos, Paraná, 2012; REBEQUE, Hernán. Historia del surgimiento, circulación y declive del periódico obrero "La Ráfaga". Tesis (Licenciatura en Comunicación) - Universidad Nacional de Entre Ríos, Paraná, 2017; LEYES, Rodolfo. Por fin la huelga quedó declarada: Una historia regional a partir del análisis de las huelgas en la Fábrica Liebig Colón, 1906-1939. e-l@tina, Buenos Aires, v. 17, n. 66, p. 6785, ene.-mar. 2019. Disponible en: https://publicaciones.sociales.uba.ar/index.php/elatina/article/view/3385. Acceso el: 13 ago. 2020; FRANCO, Julián; LARKER, José; MUSICH, Walter; VEGA, Natalia. Puertos, trabajo y conflictividad en Paraná en los primeros años del siglo XX. In: VIDELA, Oscar (comp.). Historias locales, conflictividades múltiples (Santa Fe y Entre Ríos durante el siglo XX). UNR: Rosario, 2020. p. 20-30. 


\section{La gran expansión decimonónica y la actividad urbana}

Crear pueblos de la NADA, trasplantando poblaciones a lugares donde todo lo que había era campo y las vías del tren, era un desafío para el desarrollo capitalista. Cada pueblo nuevo debía tener sus panaderías, sus herrerías, sus carpinterías, sus molinos, etc. El aumento demográfico y las nuevas demandas productivas por las actividades rurales impulsaron la emergencia de manufacturas urbanas. La reconversión de los talleres fue la forma manifiesta de aquel progreso finisecular.

Para 1914, las ramas de la producción más importantes de la provincia habían superado el piso del taller artesanal y completado el paso a la manufactura moderna, y a su vez daban lugar a un creciente proletariado urbano. El censo de 1895 indica la existencia de 1.470 establecimientos que ocupaban 10.766 obreros. En 1908, el total de establecimientos era de 1.319 y empleaban a 12.116 obreros; para 1914, los establecimientos eran 2.382 y contrataban 18.004 obreros. ${ }^{10}$ Estos números nos muestran claramente el ascenso de la clase obrera urbana.

No cabe duda que respaldado por la riqueza pecuaria provincial, se destacan por la ocupación de mano de obra asalariada las manufacturas vinculadas a la exportación de los productos de origen vacuno, en particular saladeros y fábricas de extracto de carne. En 1887 existían 8 saladeros que ocupaban 731 obreros, el número se incrementará en 1895 con 14 saladeros que empleaban 2.882 trabajadores. Para 1908 el declive de los saladeros a favor de las fábricas de extracto de carne es ostensible. Ese año existían 4 saladeros y 3 fábricas de conservas que poseían 1.043 y 1.910 obreros respectivamente. Para 1914 sólo existían 3 fábricas de conservas con 4.227 obreros, concentrando la fracción obrera más importante de la provincia. ${ }^{11}$

Mientras tanto, con la llegada de la agricultura moderna se desarrolló la industria molinera capaz de procesar los frutos de la tierra. La evolución de la rama, desde el abandono de la antigua atahona hacia el molino a vapor, significó un salto productivo de importancia. El cuadro descriptivo presentado por O'Connor es del todo útil, en tanto ilustra la vorágine en la que se trabajaba:

Sus puertas llénanse de carros y de caballos de tratantes [...] El molino, entretanto, desesperado, funciona, revuelve sus entrañas, grita y despide humo, y como al mismo tiempo está cargando y descargando incesantemente harina adentro es un infierno, pero un infierno blanco, porque en medio del ruido vibrante de la máquina, de los resplandores del fuego de las hornallas, de las chispas, del vapor y sus resoplidos, se ven

10 RepúblicA ARgentinA. Segundo Censo de la República Argentina, Censos Complementarios, Tomo III. Buenos Aires: Taller Tipográfico de la Penitenciaría Nacional, 1898. p. VII y pp. 278-279. Ibidem, pp. CXIX, 338, 355, 324, 360 y 331, respectivamente. MINISTERIO DE AGRICULTURA, Censo Industrial de la R. A. Boletín n. 3, Entre Ríos. Buenos Aires, 1909. p. 8-9. REPÚBLICA ARGENTINA, Tercer Censo Nacional, Tomo VII, Censo de las Industrias. Buenos Aires: Talleres Gráficos L. J. Rosso y Cía, 1917. p. 269-337.

11 LEYES, Rodolfo. Del saladero a la fábrica de extracto de carne: Transformaciones de los procesos de trabajo en la industria de la carne, Entre Ríos, 1864-1935. Trabajo y Sociedad, Santiago del Estero, n. 26, p. 341259, 2016. Disponible en: https://www.unse.edu.ar/trabajoysociedad/26\%20LEYES\%20RodolfoSaladero.pdf. Acceso el: 13 ago. 2020. 
por todas partes pilas enormes de bolsas llenas, blancas, que una caterva de hombres, semidesnudos, sacan afuera, por la inmensa portada, a los carros que están en la tranquera. Todo está cubierto de harina [...] De los cargadores, no hay que mentar: están blancos, aunque sean negros o cobrizos, desde que principio la molienda $[\ldots] .^{12}$

La industria harinera tuvo altibajos en nuestro periodo. Posiblemente en 1914 haya alcanzado su punto más alto, cuando se computaban 45 molinos que ocupaban 407 obreros con una capacidad instalada de 2.154 HP. ${ }^{13}$ También la industria del calzado popular, en particular de la alpargata, parece haber tenido desde el primer lustro del siglo XX un impulso particular en la provincia de Entre Ríos. Mientras en 1895 apenas se contaban 6 establecimientos, en 1909, era la tercera rama de industria que más obreros ocupaba después de los saladeros y las fábricas de conservas de carne: en 12 establecimientos trabajaban 828 obreros. ${ }^{14}$

Existe un conjunto de manufacturas que se caracterizan por su dispersión territorial, cantidad de establecimientos y ocupación de fuerza de trabajo. En el Cuadro 1 vemos la evolución de las más representativas.

\section{Cuadro 1 - Evolución de talleres y pequeñas manufacturas en Entre Ríos 1895-1914 ${ }^{15}$}

\begin{tabular}{|l|c|c|c|c|c|c|c|c|c|}
\hline \multirow{2}{*}{$\begin{array}{c}\text { Tipos de } \\
\text { Manufacturas }\end{array}$} & \multicolumn{4}{|c|}{1895} & \multicolumn{3}{c|}{1908} & \multicolumn{3}{c|}{1914} \\
\cline { 2 - 13 } & Establ. & Obreros & HP & Establ. & Obreros & HP & Establ. & Obreros & HP \\
\hline Panaderías & 130 & 440 & 44 & 140 & 805 & 165 & 141 & 1.114 & 317 \\
\hline Sastrerías & 70 & 439 & ---- & 85 & 722 & ---- & 110 & 395 & --- \\
\hline Herrerías & 164 & 473 & 131 & 181 & 549 & 106 & 217 & 399 & 200 \\
\hline Carpinterías & 223 & 944 & 193 & 177 & 720 & 191 & 192 & 876 & 424 \\
\hline Zapaterías & 157 & 509 & ---- & 120 & 527 & 6 & 16 & 448 & -- \\
\hline Imprentas & 15 & 147 & ---- & 40 & 284 & 14 & 43 & 349 & 25 \\
\hline Tabaco & 27 & 133 & --- & 34 & 625 & 7 & 47 & 832 & --- \\
\hline & Totales & $\mathbf{3 . 0 8 5}$ & & Totales & $\mathbf{4 . 2 3 2}$ & & Totales & $\mathbf{4 . 4 1 3}$ & \\
\hline
\end{tabular}

Fuentes: REPÚBLICA ARGENTINA. Segundo Censo de la República Argentina, Censos Complementarios, Tomo III, Buenos Aires, Taller Tipográfico de la Penitenciaría Nacional, 1898; MINISTERIO DE AGRICULTURA - Censo Industrial de la R. A. Boletín n. 3, Entre Ríos, Buenos Aires, 1909; MINISTERIO DE AGRICULTURA. Estadística comercial e industrial de la Provincia de Entre Ríos. Boletín n. 26, Buenos Aires, 1917.

12 O'CONNOR, Arturo. Por las colonias. Buenos Aires, L. J. Rosso, 1920. p. 117.

13 REPÚBliCA ARGENTINA. Tercer Censo Nacional, Tomo VII, Censo de las Industrias. Buenos Aires: Talleres Gráficos L. J. Rosso y Cía, 1917, p. 267 y p. 333. En adelante: REPÚBLICA ARGENTINA, Tercer Censo Nacional, Tomo VII, Censo de las Industrias... op. cit. Cf.: MINISTERIO DE AGRICULTURA. Censo Industrial de la R. A. Boletín n. 17, La Industria Harinera. Buenos Aires: 1913. p. 15.

14 REPÚBliCA ARgEnTINA. Segundo Censo de la República Argentina, Censos Complementarios, Tomo III.... op. cit., p. 278; Censo Industrial de 1909, op. cit., p. 7 y 16.

15 Se ha unificado en las sumas las carpinterías, mueblerías y aserraderos bajo el nombre de "carpinterías" para facilitar la contabilidad de la rama. En 1895 había: 196 carpinterías con 741 obreros con 91 HP, 18 mueblerías con 116 obreros y 9 aserraderos con 87 obreros y 102 HP, mientras en 1908 había: 181 carpinterías con 549 obreros, 16 mueblerías con 117 obreros y 4 aserraderos con 58 obreros. 
Estas siete actividades contrataban casi un cuarto del total de la fuerza de trabajo fabril entrerriana. Las ramas se fueron desarrollando de modo dispar: mientras las sastrerías y las imprentas aumentan en ocupación, las zapaterías parecen no guardar la tendencia general al crecimiento, razón que puede estar vinculada con la llegada de calzado importado o por la masificación de la alpargatería. La manufactura de tabaco se presentaba como una industria en ascenso que en 1912 se relevaron 118 establecimientos que empleaban 1.002 obreros, de las cuales 677 eran mujeres y 72 niños. ${ }^{16}$ Con respecto a los talleres y los salarios, Ripoll decía en 1887:

Las necesidades son tan grandes y apremiantes, que todos esos establecimientos se encuentran siempre asediados de trabajo, y faltos de oficiales y artesanos, siendo difícil que una obra cualquiera pueda ser terminada con la rapidez que el cliente desea [...] Un rasgo notable hay en la industria de Entre Ríos como en la de Santa Fe que hace esperar para ella rapidísimos adelantos, y es que, siendo tan elevados los jornales, todo industrial procura ahorrar trabajo manual por el empleo de máquinas perfeccionadas, de manera que desde la instalación de todo establecimiento, puede ofrecer al consumo artículos elaborados con todo el perfeccionamiento que introduce el empleo de la mejor maquinaria. ${ }^{17}$

Precisamente, esta tendencia al "ahorro" repercute en la incorporación de maquinarias y, por lo tanto, en la simplificación de los procesos de trabajo. Todo ello lleva a la destrucción de oficios y a la expansión del trabajo descalificado y de sus portadores, los "jornaleros". ${ }^{18}$

La gran expansión obligó también a la mejoras de las instalaciones portuarias, acordes a la nueva coyuntura productiva. Por ello, a comienzos del siglo XX se disparó la construcción, remodelación y readecuación de los puertos. En el caso del puerto de Paraná, el viejo puerto quedó obsoleto y desde 1900 comenzaron las reformas. Una situación similar sucedió en el puerto de Concepción del Uruguay, dónde además de los muelles del "puerto nuevo", entre 1899 y 1905 se abrió un canal para comunicar al puerto con el río Uruguay y se ocupó a cientos de trabajadores ${ }^{19}$.Otra revolución en el transporte se dio con el ferrocarril, que hizo desaparecer los engorrosos viajes en galera o carreta. El tendido de vías tendrá un crecimiento acelerado. Hasta 1876 la provincia tenía apenas 170 kilómetros que pertenecían al tren que hacía el trasbordo de mercancías entre Monte Caseros y Concordia, para evitar el Salto Grande del río Uruguay. Hacia 1888, los kilómetros eran 450, y en 1896, la provincia contaba con 717 kilómetros de vías de ferrocarril. Finalmente en 1912, los kilómetros de vías en toda la provincia serán $2.181 .^{20} \mathrm{El}$ tendido del ferrocarril creció doce veces.

16 SEGUNDO CENSO, Tomo III..., op. cit., p. 279; Censo Industrial de 1909, op. cit., p. 9, 16. MINISTERIO DE AGRICULTURA, Censo Industrial de la República, Boletín n 15, Manufacturas de Tabacos, Buenos Aires, Talleres Gráficos de la Of. de Met. Arg. 1912, p. 16-19.

17 RIPOLL, Cayetano. La provincia de Entre Ríos. V. II, T. II. Paraná: La Opinión, 1888, p. 25 y 113.

18 KORZENIEWICZ, op. cit., p. 73.

19 ROUSSEAUX, Andrés. Historia del puerto de Concepción del Uruguay. Tomo I. Concepción del Uruguay: Yusty, 1995. p. 109-112.

20 RIPOLL, op. cit., T. II, p. 281; Segundo Censo, Tomo III..., op. cit., p. 469; ENTRE RíOS. Ministerio de Gobierno. Dirección General de Estadística. Síntesis de la memoria anual: año 1912. Paraná: S.E., 1913. p. 26. 
En sólo dos décadas, la provincia de Entre Ríos sufrió una serie de transformaciones que cambiarían su fisionomía, imponiendo las bases de la provincia rural que conocemos hasta el día de hoy. Nuevas poblaciones, aumentos de las superficies sembradas, diversificación de las producciones, ampliación de los medios de transportes. Pero aúnW falta conocer un elemento fundamental. Cómo estas fuerzas productivas se ponían a trabajar.

\section{La clase obrera urbana y sus condiciones laborales}

EN EL ÁMBITO URBANO las condiciones laborales eran desiguales dependiendo de la fracción obrera y localidad. La jornada de trabajo promedio era entre 8 a 12 horas en 1909. En materia de salarios, el pago era muy variable según la localidad. Mientras en Gualeguaychú se pagaba entre $\$ 8$ a $\$ 1$, en Nogoyá los salarios rondaban $\$ 3,50$ a $\$ 0,35$. En tanto el costo de vida diario era de $\$ 1 .{ }^{21}$

Como ya se ha señalado, de todas las actividades urbanas, las que más obreros concentraban en la provincia eran los saladeros y fábricas de extracto de carnes, observar un caso particular nos permite conocer las condiciones generales de la rama. El establecimiento Fábrica Liebig de Colón, el más importante de la provincia, ocupaba en promedio 2.500 obreros, pero solo durante los seis u ocho meses de faena. En 1913 se trabajaban en promedio 12 horas, con una hora y media de descanso. El salario era muy segmentado, propio del carácter manufacturero de la fábrica. Dependiendo de las tareas cobraban entre $\$ 2,50$ a $\$ 8$ diarios, pero un obrero que trabaja a destajo, podía cobrar hasta $\$ 20$ por día. Las mujeres y niños estaban en un rango de $\$ 1$ a $\$ 3$. Las condiciones de trabajo no eran buenas, los obreros trabajaban casi desnudos y ensangrentados de pies a cabeza, todo bajo la mirada de un inspector que controlaba el proceso de trabajo y quién: "Sólo recibe un pequeño salario mensual, pero tiene como emolumentos las multas impuestas [al obrero] por agujerear las pieles y además, percibe el precio que el obrero habría cobrado si no hubiera agujereado la piel". ${ }^{22}$ El Departamento Nacional del Trabajo afirmó que las condiciones de salubridad eran en términos generales buenas. Aunque reconocían que los accidentes, incluso los mortales, eran comunes. ${ }^{23}$

Otras tareas urbanas que poseían altos niveles de contratación eran las panaderías. No son exageradas las palabras de Miranda, cuando recordaba a los panaderos de niñez: "Era duro y largo y riesgoso el trabajo. Duraba 10 y más horas y las noches enteras sobre

21 LEYES, Rodolfo. Trabajo, sudor y sangre. Génesis y transformaciones de la clase obrera vinculada al desarrollo agrario y manufacturero en Entre Ríos, 1858-1946. Tesis (Licenciatura en Historia) - Universidad Autónoma de Entre Ríos, Concepción del Uruguay, 2013. Datos preliminares para el Censo obrero de la República Argentina. Boletín del Departamento Nacional del Trabajo, n. 8, 1909. p. 15.

22 Condiciones del trabajo en la República Argentina. Boletín del Departamento Nacional del Trabajo, n. 25, p. 830-835, 1913; LLOYD, Reginald. Impresiones de la República Argentina en el siglo veinte: su historia, gente, comercio, industria y riqueza. Londres, Buenos Aires: Lloyd's Greater Britain Publishing, 1911. p. 272-275.

23 Condiciones del trabajo en la República Argentina. Boletín del Departamento Nacional del Trabajo, n. 25 , 1913. p. 832. 
todo. A más la cuadra era un horno, afuera helada y los panaderos desnudos, apenas con un chiripacito salían y entraban". ${ }^{24}$ En efecto, la exposición al calor del horno y la temperatura ambiente, generaban problemas respiratorios a los trabajadores, mientras el trabajo nocturno ocasionaba problemas en la piel de los obreros, siempre expuestos a la luz artificial. ${ }^{25}$ Por su parte los albañiles, una de las fracciones más numerosas de la clase obrera entrerriana, se desempeñaban bajo la dirección de un obrero especializado o para una empresa:

El ferrocarril llegará pronto a Villaguay. Hay que hacer el puente sobre el arroyo, construir la estación, tender los rieles. Toda esa gente ha venido a ello, después llegaron más y más albañiles italianos. El puente, la estación y las vías no eran las únicas que los requerían. También los baldíos, los tapiales, las veredas, los ranchos de terrón y paja, las tierras vírgenes y las casas envejecidas, todos necesitaban de sus manos hábiles $[\ldots]^{26}$

La construcción de vías férreas ocupó siempre a miles de trabajadores. Un diario de 1906 decía: "Para las obras emprendidas por la empresa de los ferrocarriles de Entre-Ríos, se calcula que para fines del corriente alcanzarán a 1.500 personas empleadas en la construcción de ramales...". ${ }^{27}$ Es decir, durante el tiempo de una construcción se podía ocupar la misma cantidad de obreros que un saladero.

Otros empleos tenían un fuerte componente femenino, como era el caso de las lavanderas. Estas mujeres se encargaban del lavado de la ropa en algún curso de agua cercano. Según cuenta el colono judío David Gorskin, cuando se fundaba un pueblo se mantenía una franja de tierra "libre" a fin que las lavanderas tengan lugar para ir a lavar las ropas y mantener su oficio. ${ }^{28}$ La demanda permanente de los servicios hacía que su trabajo se mantuviera continuo. Las tareas de estas mujeres era "consumida" por toda la sociedad, que a un módico precio - tarifa que aumentaba en tiempos de sequía ${ }^{29}$ - permitía su subsistencia.

Otra actividad de económica que contrataba mucha mano de obrera era la estiba. Trabajo que depende de la producción rural y se realiza en buena medida en las estaciones férreas del ámbito rural y en los puertos, donde los estibadores hacían la carga y descarga de bolsas a los barcos o trenes. Bialet Massé se refería a la situación de estos trabajadores en su informe de 1903:

La carga y estiba desde Paraná inclusive río arriba se mantiene en las condiciones absurdas de antaño. En el Paraná, la carga en Bajada Grande ó sea ahora Puerto Nuevo, exige, cuando no se hace de vagón á buque, que el obrero lleve la bolsa una distancia enormemente grande; aquel es peor que trabajo de negros. A este obrero, en peores condiciones que en Colastiné [Santa Fe], que está á la vista, como Santa Fe, se le paga mucho menos [...] El trabajo extraordinario se paga doble. El señor gerente de la casa dicha me

24 MIRANDA, Justo José. Villaguay: Mi Pueblo. Entre Ríos: Comarca, 1978. p. 81.

25 FALCÓN, Ricardo. El mundo del trabajo urbano (1890-1914). Buenos Aires: CEAL, 1986. p. 22 y ss.

26 MIRANDA, op. cit., p. 83.

271500 empleados. El Entre Ríos, Colón, p. 1, 10 abr. 1906.

28 GORSKIN, David. Reflejos Entrerrianos para niños y adultos. T. III. Rosario: Entre Ríos, 1975. p. 203; MIRANDA, op. cit., p. 38.

29 BARCÓN OLESA, Juan. El estado de Entre Ríos. Álbum gráfico y exposición sintética de sus elementos de progreso. Paraná: S/E, 1912. p. 29. 
informó que los estibadores del Paraná son fuertes, muy buenos trabajadores y honrados, que son en su casi totalidad criollos; no hay muchos borrachos, y son faltadores los lunes. ${ }^{30}$

Afirmaba el funcionario de Roca que por la falta de empleo continuo, los obreros vivían a disposición del patrón "y cualquiera que sea el jornal no le alcanza para vivir. De ahí que tiene que someterse á las exigencias más tiránicas"; al respecto de las condiciones de trabajo de los estibadores entrerrianos Bialet Massé indicaba:

La jornada es de nueve horas; tiene descanso dominical, pero si hay trabajo, y lo piden, se les da; si se necesitan para una carga urgente, se les paga doble. Ahora bien, en el Paraná, como en casi todos los puertos de Entre Ríos, la situación del obrero estibador es muy precaria. Los accidentes de trabajo no se pagan. Me han dicho dos cargadores que la ley no los manda pagar. $^{31}$

El autor del Informe sobre el estado de la clase obrera en Argentina afirma en tono de crítica que los empresarios molineros insistían en el uso de las bolsas de 90 kilos. Las consecuencias del trabajo con tales cargas, son fáciles de imaginar: "Fortachando en el Paraná una bolsa de arroz con peso de 110 kilos, se descaderó en la estación del ferrocarril el peón Santos Narvaes". ${ }^{32}$ Noticias de este tipo se leen con frecuencia en los diarios de la época.

Este repaso alcanza solo a una porción de las fracciones obreras. Hemos descubierto para 1895 más de sesenta profesiones y ocupaciones obreras, número que asciende a más de ciento diez en $1914 .{ }^{33}$ Lo que nos da una dimensión de la diversidad de situaciones contractuales, de pagos y condiciones del proletariado entrerriano.

\section{"Agitadores profesionales" o técnicos obreros en la lucha de clases}

UNA DE LAS PREGUNTAS que disparó este trabajo fue: ¿cómo se forma la organización obrera en espacios dónde antes no existía? Desde luego que el primer requisito es la existencia de clase obrera, es decir, un grupo de personas que vivan de la venta de fuerza de trabajo y que, a través del salario, consigan los medios de vida suficientes para continuar reproduciendo su vida. Con esto dejar claro entonces que primero hace falta el grupo humano que viva en aquellas relaciones sociales para luego preguntarnos en qué momento y porqué motivos se decide pasar, de la lucha individual e inorgánica, a la organización gremial.

Nuestra hipótesis de trabajo es que, en ambientes sociales donde no existe la organización esta viene de afuera gracias a la acción de militantes que se movilizan a esos territorios, algunas veces de modo espontáneo y otras de acuerdo a planes más o menos acordados, y cargan con la capacidad organizativa. Estos militantes tienen no solo

30 BIALET MASSÉ, op. cit., T. I, p. 397-398.

31 Ibidem, p. 397-398. Cursiva en el original.

32 Por Hacer Fuerza. El Entre Ríos, Colón, p. 1, 14 abr. 1904.

33 Segundo Censo: 1895: Población... v. 2, op. cit. Tercer Censo Nacional, Tomo IV, Población..., op. cit., p. 236-246. 
la función de pensar los problemas sociales sobre los que pretenden intervenir, sino, y mucho más difícil, explicar la necesidad de elegir el camino por ellos propuestos. Podemos decir, siguiendo a Gramsci, que se trata de intelectuales orgánicos ${ }^{34}$ de la clase obrera abocados a la intervención en las relaciones sociales de producción. Porque aún aquellos que proponían un horizonte político para la superación del capitalismo - anarquistas y socialistas - encontraron sus nichos de militancia en impulsar el movimiento obrero, aunque esto no los privó de continuar su tarea proselitista a favor de una ideología.

Entonces, un territorio en apariencia "virgen" de organización obrera, es "colonizado" por militantes que importan la experiencia adquirida afuera, en otro centro de acumulación capitalista. Algo que originalmente se planteó para explicar la temprana conflictividad en los saladeros de Justo José de Urquiza en la década de 1850-1860 y la potencial vinculación entre la experiencia de los obreros de origen vasco con los obreros locales que allí se ocupaban (LEYES, 2014). Ahora bien, esa posibilidad, la de una organización a partir de agentes obreros externos al territorio, se puede comprobar en el periodo y estudio de caso.

Una pregunta pertinente sería si sólo vía la acción externa es que se logra la organización y nos inclinamos por un rotundo no. En primer lugar porque no hemos encontrado prueba de la creación de todos los gremios existentes, algunos de sospechosa antigüedad como la Federación Obrera Victoriense o los sindicatos creados en la localidad de Concordia. Asimismo, han existido varias huelgas que se produjeron sin un aparente agitador externo que perteneciera a alguna organización específica, tales como las huelgas de obreros de la construcción de las vías ferroviarias de Concepción del Uruguay, los obreros de canteras de Paraná o de los canales de navegación de Victoria. ${ }^{35}$ Todos hechos que pueden confirmar la autonomía y espontaneidad de la lucha gremial.

Sin embargo, las luchas aisladas, así como la organización local sin vínculos aparentes con el exterior provincial, necesitan ser estudiados minuciosamente para descartar al militante solitario que emprende la tarea de organizar y por otro lado, reconsiderar estas experiencias de cara a los movimientos más generales del proletariado argentino en torno a las centrales obreras que irán surgiendo en las últimas décadas de 1890. Por último, existiendo un lapso de tiempo inexplorado, comprendido entre la mitad del siglo XIX hasta fin de siglo, es necesario avanzar en estudio sobre el conocimiento de la lucha de clases y la organización obrera comprendido dentro de aquel.

Ahora bien, los primeros registros que tenemos de acción proselitista y organizativa fue la llegada del militante anarquista Pietro Gori a la ciudad de Paraná, capital provincial, y Rosario del Tala en octubre de 1899. Su actividad transcurrió por medio de conferencias con un contenido fuertemente doctrinal, a pesar de ello, la conferencia pública en Paraná

34 GRAMSCI, Antonio. Los intelectuales y la organización de la cultura. Buenos Aires: Nueva visión, 2003. p. 13.

35 Noticias De Una Huelga. La Juventud, Concepción del Uruguay, p. 1. 11 oct. 1906. Por Las Provincias. La Protesta, Buenos Aires, p. 2, 6 sep.1904; ENTRE RIOS-Huelga De Peones. La Protesta, Buenos Aires, p. 1, 2 jul.1904. 
se dio en la Escuela Normal, institución que servía también de centro convocante del liberalismo vernáculo. ${ }^{36}$ No fueron los únicos casos, en 1902 se trazaba una nueva gira de los militantes anarquistas, y las ciudades de Paraná y Rosario del Tala volvían a ser parte del derrotero trazado, lo que da cuenta de la existencia de grupos de militantes allí también. ${ }^{37}$ En noviembre de 1904 un nuevo grupo de anarquistas llegó a Paraná desde Rosario, provincia de Santa Fe. Los ácratas dieron una serie de conferencias sobre la organización obrera y con un alto contenido anticlerical y antiestatal. ${ }^{38}$ Su actividad venía apuntalar la labor de otros anarquistas que habían lanzado el llamado a la creación de la Federación Obrera Entrerriana, una suerte de federación de oficios varios que se había creado aquel año. Pero estas visitas aisladas, cambiaron radicalmente en 1904 cuando militantes de la ciudad de Santa Fe, capital de la provincia homónima, cruzaron el río Paraná a la capital entrerriana y comenzaron allí la organización de los obreros locales "entusiastas por el ideal de redención humana y poco avezados a las luchas económicas". ${ }^{39}$ Este tipo de gira de organización y propaganda se repitieron en varias ocasiones a lo largo de los años siguientes y su papel fue fundamental para la organización gremial, en especial de la costa del río Paraná. ${ }^{40}$

Pero no fueron solo los anarquistas los que recurrieron a esta forma de construcción, los socialistas desde temprano buscaron vincular su organismo con los militantes locales. Lo primero que deberíamos decir es que en el congreso fundacional del Partido Socialista (PS) en junio de 1896, los representantes de la seccional Paraná, no fueron entrerrianos sino los delegados Adrián Patroni y Antonio Varela de Buenos Aires. ${ }^{41}$ Pero ya en 1906 , los miembros del PS propusieron a los militantes de la Unión General del Trabajadores (UGT), de filiación socialista en su mayoría, compartir los gastos de una gira por la provincia y en 1910, era el turno de los sindicalistas de visitar la provincia con la intención de organizar a los trabajadores ${ }^{42}$.

Estos tipos de giras de organización tendrán sus momentos de mayor resultado en el ciclo de luchas obreras que se extendió entre $1917-1921^{43}$ pero lo que a nosotros interesa es señalar la importancia evidente que significó ese método táctico para organizar a los trabajadores. Los delegados gremiales sirvieron como verdaderos "catalizadores externos" al

36 Correspondencia. La Protesta Humana, Buenos Aires, p. 3, 15 oct. 1899. Correspondencia. La Protesta Humana, p. 3, 19 abr. 1902.

37 Gira De Propaganda. La Protesta Humana, Buenos Aires, p. 3, 5 abr. 1902. Gira De Propaganda. La Protesta Humana, Buenos Aires, p. 3, 19 abr. 1902.

38 La Gira De Propaganda. La Protesta, Buenos Aires, p. 3, 16 nov.1904,

39 Movimiento Obrero. La Protesta, Buenos Aires, p. 3, 10 dic. 1904.

40 Movimiento Obrero. La Protesta, Buenos Aires, p. 3, 16 ene. 1907; Movimiento Obrero. La Protesta, Buenos Aires, p. 3, 11 jul. 1907; Movimiento Obrero. La Protesta, Buenos Aires, p. 3, 16 ene. 1906; La Prisión De Los Delegados En Gira. La Protesta, Buenos Aires, p. 1, 26 ene. 1914

41 ODDONE, Jacinto. Historia del Socialismo argentino. T. I. Buenos Aires: CEAL, 1983. p. 59.

42 La Unión Obrera, Buenos Aires, mar. 1906. Informe del delegado al salto oriental. Confederal, Buenos Aires, mar. 1910.

43 LEYES, Rodolfo. La estrategia de sindicalización de la FORA del IX ${ }^{\circ}$ en el oriente entrerriano (1917-1921). Conflicto Social, Buenos Aires, a. 2, n. 2, p. 34-48, dic. 2009. Disponible en: https://publicaciones.sociales. uba.ar/index.php/CS/article/view/422/380. Acceso el: 13 ago. 2020. 
medio obrero local, pero que permitieron establecer las bases para que el movimiento obrero no desfallezca producto de las complejidades prácticas que su praxis generaba.

\section{Los primeros pasos: socialistas y anarquistas}

A FINES DE 1873 fue sofocada por las fuerzas nacionales la última sublevación caudillista en la provincia de Entre Ríos. El levantamiento de Ricardo López Jordán había terminado con la vida de Justo José de Urquiza y la provincia era amenazada de caer en un nuevo ciclo de guerras civiles. ${ }^{44}$ Las lanzas de López Jordán no pudieron contra los fusiles Remington del gobierno de Sarmiento. En ese cruce de caminos, en suelo entrerriano, se encontraba el belga Raymond Wilmart, el delegado de Karl Marx para organizar la Primera Internacional en la región occidental del río de La Plata. Wilmart había comenzado su militancia como anarquista hasta que se convenció por el marxismo por intermedio del yerno de Marx, Paul Lafargue. Luego del congreso en La Haya, dónde se expulsó a los anarquistas dirigidos por Mijail Bakunin, se decidió enviar delegados de la Internacional a varios países a organizar secciones locales. Como los bakuninistas eran fuertes en Montevideo, se pensó en establecer un polo marxista entre los emigrados europeos que vivían en Buenos Aires. Wilmart envió tres cartas a Marx sobre la situación en aquella ciudad, concluía que las posibilidades de ascenso social dificultaban la militancia revolucionaria. En la segunda mitad de 1873 se enroló en el ejército nacional y se dirigió a Entre Ríos a sofocar la rebelión jordanista. Este es el primer registro de un marxista en el territorio de estudio. ${ }^{45}$

La existencia de socialistas en la provincia, de modo estable, se remonta al menos a 1893 cuando se imprimió un periódico llamado Primero de Mayo en Paraná. Más adelante, un grupo de marxistas fundaron un club socialista en Paraná, al parecer, en diciembre de 1895: "Los compañeros de Paraná, no podían permanecer indiferentes ante el movimiento que hoy se inicia y ellos también se han congregado y fundado un Centro socialista obrero en aquella localidad. Es indudable dado el número de trabajadores que existen en el Paraná". ${ }^{46}$ Al año siguiente se editaba un periódico llamado El Socialista, órgano del Partido Obrero Socialista. Pero esto no fue todo, como señala el historiador del socialismo entrerriano, Jorge Villanova, pronto los socialistas constituyeron el primer centro socialista en Concordia en 1896, luego se presentaron a elecciones en 1899 y lograron ubicar a dos miembros suyos en el Concejo Deliberante de Gualeguaychú, hecho repetido en 190147. Según Oddone,

44 DJENDEREDJIAN, Julio. Tormenta perfecta. La rebelión jordanista en Entre Ríos y los efectos del ciclo económico, 1864-1873. In: SANTILLI, Daniel y otros. Rebeldes con causa: conflictos y movilización popular en la Argentina del siglo XIX. Buenos Aires: Prometeo libros, 2013. p. 169-195.

45 TARCUS, Horacio. Marx en la Argentina: sus primeros lectores obreros, intelectuales y científicos. Buenos Aires: Siglo XXI Editores, 2013. p. 84-103.

46 La Vanguardia, Órgano del Partido Socialista Obrero, 7 dic. 1895 apud VILLANUEVA, Jorge. EI Partido Socialista en la primera década del siglo XX en Concepción del Uruguay. Concepción del Uruguay: Clara Chauvin Editora, 2018. p. 5.

47 Ibidem, p. 6-7. 
las elecciones legislativas de 1904 encontraron centros socialistas en Concepción del Uruguay - fundado en $1901^{48}$ - y Concordia. ${ }^{49}$ Un hecho a remarcar es la desaparición del centro de Paraná. En las elecciones de 1906, el Partido Socialista (PS) ganó en Concepción del Uruguay tres concejalías, lo que era un hito celebrado en el boletín interno del partido: “...los tres compañeros que han recibido la misión de mantener nuestros principios en antagonismo con las camarillas criollas...". En paralelo, crearon un periódico que duró poco tiempo Ilamado Idea Obrera. De los tres ediles, dos renunciaron a sus bancas, uno por trabajo y otro por mudarse a España. ${ }^{50}$

La creación de los centros socialistas no significaba su consolidación. En 1907, los socialistas de Concepción del Uruguay intentaron sin éxito construir una Casa del Pueblo, pero los fondos no se lo permitieron y decidieron donar el dinero. ${ }^{51}$ Otro ejemplo, en 1915 los socialistas de Colón escribían a sus pares uruguayenses sobre qué hacer en las elecciones, dado que no tenían candidatos: "En esta irán a la lucha por partidos el demócrata y el Radical y hai [sic] algunos simpatizantes socialistas que no saben si dar los votos a los demócratas o abstenerse.... ${ }^{52}$ En los primeros meses de 1917 el secretario general de la sección Concepción del Uruguay del PS recibió una carta desde Paraná a su pedido de un delegado para el primero de mayo: “...no obstante su deseo favorable al pedido en cuestión no le será posible satisfacerlo en virtud de la situación precaria porque nuestro Centro atraviesa...". ${ }^{53}$

Si bien el partido encontró en la política electoral su nicho, el PS tuvo militancia entre los trabajadores. Por ejemplo, los socialistas de Concepción del Uruguay fueron los encargados de realizar, por primera vez en esa ciudad, la conmemoración del Primero de Mayo en 1902. ${ }^{54}$ También existen menciones a la intervención de socialistas en la primera huelga de la Fábrica Liebig en 1906 e invitaciones al gremio Carreros Unidos de Concepción del Uruguay a cotizar para la construcción de la Casa del Pueblo local. ${ }^{55}$

Los socialistas argentinos decidieron participar de un escenario difícil, hegemonizado por la burguesía criolla, y enfocados en una población inmigrante con pocas intensiones de participación institucional. Mientras el ambiente gremial tenía mucho potencial, dadas las condiciones de explotación de los obreros y las masas desorganizadas. Oportunidad que fue aprovechada por los anarquistas.

48 Ibidem, p. 10.

49 ODDONE, op. cit., T. II, p. 258-259.

50 VILLANOVA, op. cit., p. 35-37; La Juventud, Concepción del Uruguay, 5 abr. 1906.

51 Casa del Pueblo. La Juventud, Concepción del Uruguay, p. 1, 3 sep. 1907; Casa del Pueblo. La Juventud, Concepción del Uruguay, p. 1, 6 ago. 1908; Casa del Pueblo. La Juventud, Concepción del Uruguay, p. 1, 10 dic. 1908

52 ALBIZZATTI, José [Correspondencia] Destinatario: KANNER Jaime Colón, 1 dic. 1915, PARTIDO SOCIALISTA, Centro Socialista de Concepción del Uruguay, Libro de Notas del Centro Socialista de Concepción del Uruguay, s/p.

53 SECRETARIO DEL CENTRO SOCIALISTADE PARANÁ [Correspondencia] Destinatario: Secretario del Centro Socialista de Concepción del Uruguay, Paraná, 19 abr. 1917, PARTIDO SOCIALISTA, Centro Socialista de Concepción del Uruguay, Libro de Notas del Centro Socialista de Concepción del Uruguay, s/p.

54 VILLANOVA, op. cit., p. 13.

55 La huelga en el Saladero Colón. sociedades gremiales. La Juventud, Concepción del Uruguay, p. 1, 24 mar. 1906; Casa del Pueblo. La Juventud, Concepción del Uruguay, p. 1, 1 oct. 1907. 
Las últimas décadas del siglo XIX y la primera del siglo XX fueron la edad de oro del anarquismo en el río de La Plata. La llegada masiva de inmigrantes franceses, españoles e italianos, sirvieron de puente entre el viejo y nuevo mundo. Pocos años después el anarquismo se ve estimulado por la llegada de militantes de talla mundial como los italianos Errico Malatesta y Pietro Gori, quién incluso, como se indicó más arriba, visitó la provincia. Pero no fue hasta la década de 1890 cuando el anarquismo, unido a un movimiento obrero en ascenso, se convierte en un movimiento de masas y comienza a tener una expansión territorial de alcance sin precedentes. Influjo que durará por lo menos hasta la década de 1910, cuando la represión del Centenario, cambios en la economía argentina y la apertura política por la Ley Sáenz Peña de 1912 los empujaron a una situación de reflujo ${ }^{56}$.

En Entre Ríos la presencia del anarquismo se hace difícil de datar por la particularidad de su militancia, con una baja organicidad y la permanente reformulación de los grupos de pertenencia. Sin embargo, el histórico periódico anarquista La Protesta Humana ${ }^{57}$ de Buenos Aires, incluye algunas menciones que vale la pena repasar. En 1897 se encarcela en la localidad de Victoria a un obrero carpintero anarquista italiano acusado por el atentado al Primer Ministro de Italia en 1894. Un obrero informaba que se encontraba incomunicado y esperaba la extradición a pedido del consulado italiano. En otra nota se daba cuenta de la formación de un círculo de afinidad en Rosario del Tala con el nombre de Los sin Patria. Otros medios locales informaban, con un halo conspiranoico, la potencial existencia de anarquistas en Concordia: "De fuente oficial ha llegado a nuestro conocimiento que la policía tiene el hilo de una madeja anarquista enrollada á nuestra sociedad". ${ }^{58}$

La aplicación de la Ley de Residencia - mecanismo legal que permitía la expulsión de inmigrantes considerados "indeseables", mayoritariamente obreros que buscaban organizarse sindicalmente ${ }^{59}$ - afectó a los núcleos anarquistas entrerrianos cuando se pidió la expulsión de algunos de sus militantes. ${ }^{60}$ Colateralmente, la región de la costa del río Uruguay, frontera entre la Argentina y la República Oriental del Uruguay, era puerta de reingreso de muchos expulsados. ${ }^{61}$

Como hemos indicado, desde las últimas décadas del siglo XIX comenzó a desarrollarse con fuerza una vertiente anarquista vinculada a los sindicatos que se consolidó en 1901 en torno a la Federación Obrera Argentina. A la que en 1904 se le agregó la palabra Regional, para dar vida a las siglas F.O.R.A. Esta corriente anarquista tuvo su expresión en Paraná, cuando un puñado de militantes creó el periódico La Ráfaga: ${ }^{62}$

56 BILSKY, Edgardo. La F.O.R.A. y el movimiento obrero (1900-1910). Buenos Aires: CEAL, 1985 y FRYDENBERG, Julio y RUFFO Miguel: La semana Roja de 1909. Buenos Aires: Ediciones RyR, 2012.

57 La Protesta Humana pasó a llamarse sólo La Protesta desde 1904.

58 Desde Victoria. La Protesta Humana, Buenos Aires, p. 3, 28 nov. 1897; Progresando. La Protesta Humana, Buenos Aires, p. 4, 21 ene. 1900; ¿Anarquistas en Concordia? El Entre Ríos, Colón, p. 1, 19 ago. 1900.

59 OVED, laacov. El trasfondo de la Ley $n^{\circ} 4.144$ de Residencia. Desarrollo Económico, Buenos Aires, n. 61 , v. 6, p. 123-150, abr.-jun., 1976.

60 Lista Negra. La Protesta Humana, Buenos Aires, p. 1, 7 feb. 1903.

61 EI Entre Ríos, Colón, p. 1, 19 sep. 1906.

62 Para un análisis de La Ráfaga ver: REBEQUE, op. cit. 
Un núcleo de compañeros entusiastas y decididos a luchar por la emancipación de la humanidad entera ha resuelto la publicación de un periódico que sea la expresión genuina de los sentimientos de aquellos que sufren con nosotros las injusticias del régimen imperante [...] LA RÁFAGA entonces, será eso, defensor de los humildes y de los caídos, pregonero entusiasta de todas las verdades y látigo implacable contra todas las mentiras. ${ }^{63}$

En el número 2 del periódico aclararon que ellos, como anarquistas y obreros, intervenían en la vida de los gremios de la localidad pero advertían que “...no entendemos la organización como un medio de conseguir mejoras, simplemente, pues, si bien reconocemos que estas alivian en parte al proletariado, sabemos también que no resuelven el problema social." Por ello proponían hacer propaganda anarquista dentro de las agrupaciones obreras. El grupo de La Ráfaga organizaba conferencias y actividades culturales, como obras de teatros desde su cuadro filodramático del mismo nombre que el periódico: "En pocas ocasiones hemos presenciado en esta localidad, las grandes asambleas de propaganda que se han desarrollado en el mes pasado [...] Satisfechos del gran éxito obtenido en lo que a la propaganda de las ideas anarquistas se refiere...", los autores de la nota recordaban una actividad organizada en la Sociedad Italiana de Paraná que había congregado una gran cantidad de público, destacando la presencia de mujeres: "El camarada Giovetti quién improviso un elocuente discurso sobre cuestiones generales de la propaganda y terminó con un llamado a los proletarios en general para que ingresen en las organizaciones obreras". ${ }^{64}$ Meses más adelante lograron fundar su propia sala de teatro en el local obrero dónde se reunían. ${ }^{65}$ Así, la propuesta cultural se conjugaba con la participación en el gremio. En este sentido, los ácratas desarrollaron una militancia política integral para difundir sus ideales revolucionarios. Desde octubre de 1908, La Ráfaga se volvió el órgano de la Federación Obrera Entrerriana y comenzó a llevar un membrete debajo de su nombre indicando la filiación. Pero la coyuntura nacional vendría a golpear a los anarquistas. Hernán Rebeque, concluye que el declive de La Ráfaga estuvo vinculado a la represión del centenario. ${ }^{66}$ No obstante, entre septiembre de 1909 y enero de 1910 no hay publicaciones, lo que pueden ser señales de problemas económicos.

Los años siguientes a 1910 se reconoce una fuerte anomia de parte del proletariado entrerriano que se refleja en las consecuentes quejas de los militantes: "Un proletariado sin energías, sin voluntad, necio y torpe". ${ }^{67}$ En 1913 se intenta relanzar la organización en Paraná, aunque buena parte de los militantes habían abandonado la ciudad. Para impulsar la propaganda se creó el periódico El Obrero Entre-Riano, órgano de la Federación Obrera Entrerriana. ${ }^{68} \mathrm{~A}$ pesar del impulso, no se llegó a la reorganización y al poco tiempo volvieron los traspiés. Los obreros no respondieron a los llamados, los militantes de Buenos Aires que llegaban

63 A Los Compañeros y Trabajadores De Paraná. La Ráfaga, Paraná, p. 2, 15 jul. 1908. Mayúsculas en el original.

64 DE LA PROPAGANDA. La Ráfaga, Paraná, p. 4, 1 sep. 1908.

65 Vida obrera y propaganda. La Ráfaga, Paraná, p. 4, 1 dic. 1908.

66 REBEQUE, op. cit., p. 78.

67 Del Interior. La Protesta, p. 3, 19 dic. 1911

68 Corresponsal. La Protesta, p. 3, 9 feb. 1913; Corresponsal. La Protesta, p. 3, 16 feb. 1913. 
hacer propaganda eran encarcelados y finalmente se abandonó el local de la Federación Obrera Entrerriana: “... la Federación constreñida a reducirse en un insignificante rincón...”, habían dejado el local a los socialistas. ${ }^{69} \mathrm{Al}$ año siguiente, un grupo de militantes anarquistas vendieron los muebles de la Federación Obrera sin autorización de sus compañeros. ${ }^{70}$ Era el fin de esta primera época del anarquismo entrerriano.

\section{Las luchas sindicales y sus obstáculos prácticos}

LA EXPANSIÓN CAPITALISTA no solo produjo un crecimiento inusitado de las fuerzas productivas sino también de las contradicciones de clase en su seno. La década de 1890 conoció un incremento de la actividad gremial en el litoral argentino, en especial en el eje Buenos AiresRosario. En ese contexto, los marineros de la Sociedad de Resistencia y Protección Mutua de Buenos Aires fueron a huelga en la primera quincena de 1895, pocos días después el puerto de Diamante se veía contagiado de aquella huelga. ${ }^{71}$ Sin embargo, no hemos encontrado otros conflictos desde esa fecha hasta el paso de siglo, cuando se formaron los primeros sindicatos.

La voluntad militante y las contradicciones de clases no alcanzan para que la organización obrera se materialice. Los intentos de organización tropezaban con la apatía de los obreros como primer obstáculo. Desde las páginas de La Ráfaga, el periódico anarquista de Paraná se decía:

Si dijéramos que en esta región la explotación capitalista no se siente con el peso de otras localidades, si los proletarios vivieran aquí más desahogadas que en otras partes y por último si aquí no sufrieran todas las calamidades y oprobios del régimen actual, si todo esto fuera, podrían justificar en algo su actitud de apatía e indiferencia, porque tendrán el recurso de objetar su mejor bienestar [...] pero la explotación es de los más refinada que pueda conocerse, si la vida es un calvario de miserias, si todo es malo y pernicioso de nuestra época, se siente aquí con tanto o mayor rigor que en otras partes. ¿Por qué esa sumisión? ${ }^{72}$

Un cuadro que representa estas situaciones fue relatado para La Ráfaga, cuando algunos anarquistas intentaron organizar a los gráficos de Paraná: "El trabajo que tuvieron para convencer a esos ignorantes [...] fue tanto y tan grande que sería imposible relatarlo." El narrador indicó que no había entre los obreros ningún espíritu de lucha y que lo lógico hubiera sido abandonar el intento de organización. Pero continuaron: "Llegó por fin el día señalado para la reunión. La hora indicada se acercaba y el número de compañeros era tan escaso que casi no nos atrevimos a reunirnos por no ser objetos de críticas de parte de los inasistentes (sic)..." ${ }^{73}$

69 La Prisión De Los Delegados En Gira. La Protesta, p. 1, 28 ene.1914. Paraná; La Protesta, p. 4, 10 abr. 1915 ; Paraná. La Protesta, p. 3, 22 ene. 1915.

70 De Paraná. La Protesta, Buenos Aires, p. 3, 31 mar. 1916.

71 CARUSO, Laura. Embarcados. Los trabajadores marítimos y la vida a bordo: sindicato, empresas y Estado en el puerto de Buenos Aires, 1889-1921. Buenos Aires: Imago Mundi, 2016. p. 96-98.

72 Necesidad de organizarse. La Ráfaga, Paraná, p. 1, 15 jul. 1908.

73 Ibidem, p. 4. 
La segunda dificultad que encontraban era la intransigencia patronal. Lo primero que hacía un patrón cuando descubría o era notificado de la creación de una "sociedad de resistencia", como gustaban llamar a los sindicatos los anarquistas, era el despido de los obreros vinculados a la organización. Es decir, romper el vínculo entre obreros y los cuadros gremiales que le daban un horizonte. Esto sucedió tan temprano como en 1901 cuando los obreros de la Metalúrgica Aranguren - uno de los grandes productores de maquinaria rural de la provincia - se organizaron y se procedió al despedido del obrero encargado de la organización: "Los burgueses andan muy asustados por el despertar de la clase obrera de esta [Paraná] y ya empezaron a vengarse con los obreros que son alma del movimiento y que con más ahínco propagan la organización". ${ }^{74}$ Este recurso básico del repertorio patronal contra los trabajadores se repitió una y otra vez en los años y conflictos siguientes.

Otro problema con el que se encontraron los trabajadores fue el control y represión estatal. En particular los anarquistas encontraron un freno en la policía de la provincia que no dudaba en encarcelar a los obreros organizadores, algunos con arbitrariedades graves como allanamientos y encarcelamientos por posesión de propaganda anarquista. $\mathrm{O}$ en momentos de conflictos la actitud estatal era mayoritariamente represiva. ${ }^{75}$ Un caso de estos se produjo en septiembre de 1905 en Gualeguay cuando un delegado solicitó el permiso de reunión a la policía. El comisario no solo lo otorgó el permiso sino que felicitó por la iniciativa de organizarse para mejorar las condiciones de los obreros, pero el día de la reunión se hizo presente un grupo de policías y obligaron a los obreros a dispersarse por orden del comisario, los obreros se preguntaban si era simple arbitrariedad o si se había hecho eco de las quejas de los burgueses locales. ${ }^{76}$

En los conflictos más grandes, tomemos por caso la huelga de Liebig de 1906, encontramos la superposición de la coerción estatal y patronal contra la organización obrera. Los obreros de la Fábrica Liebig generaron su primer conflicto tres años después de que se fundara el establecimiento, el motivo de la huelga fueron las diferencias salariales que tenían los obreros de Liebig Colón con sus pares de Fray Bentos, Uruguay. ${ }^{77}$ La gerencia de la fábrica no se ocupó del petitorio presentado por los obreros a quienes despidió de inmediato e intervino la policía, a bayoneta calada según informó un periódico, y se ocupó de custodiar a los despedidos. También aplicaron la Ley de residencia a los trabajadores extranjeros - muchos de origen uruguayo y posiblemente los promotores del conflicto - y se procedió al desahucio

74 A los Compañeros Metalúrgicos de la República Argentina. La Protesta, Buenos Aires, p. 3, 14 dic. 1901.

75 Algunos pocos casos, pero que se repiten en casi todos los casos de huelgas: Movimiento Obrero. La Protesta Humana, Buenos Aires, p. 3, 23 ago. 1902; Lista Negra. La Protesta Humana, Buenos Aires, p. 1, 7 feb. 1903; Paraná. La Protesta, Buenos Aires, p. 3, 17 nov. 1904; Interior-Gualeguay. La Protesta, Buenos Aires, p. 3 , 18 jul. 1905; Paraná. La Protesta, Buenos Aires, p. 3, 8 jul.1906; La Policía en acción. La Protesta, Buenos Aires, p. 2, 10 ago. 1913.

76 Interior-Gualeguay. La Protesta, p. 3, 12 sep. 1905.

77 Las huelgas de la Liebig se han desarrollado en LEYES, op. cit.; Lo de Fábrica Colón. El Entre Ríos, Colón, 20 mar. 1906; La huelga. El Entre Ríos, Colón, p. 2, 31 mar. 1906. La Juventud se presentaba un cuadro comparado de los salarios, mostrando el verdadero desfasaje existente entre los obreros de la Liebig Fray Bentos frente a sus pares de Liebig Colón. Cf.: Fray Bentos y Colón. La Juventud, Concepción del Uruguay, p. 2, 31 mar. 1906. 
de las viviendas que se alquilaban a los obreros y que eran propiedad de la empresa. Mientras tanto, el establecimiento fue ocupado por unos doscientos uniformados. ${ }^{78}$ La primera huelga de la Liebig Colón duró poco más de una semana y terminó con el despido de unos 600 obreros. En tanto la empresa inglesa agradecía al gobernador y regaló al comisario local un reloj de oro en gratitud por los servicios. ${ }^{79}$

Empero, estas dificultades no significaba que fuera imposible la organización gremial. Para 1905 estaban afiliados a la Unión General del Trabajo los sindicatos de Obreros del Puerto, panaderos y albañiles de Concordia. ${ }^{80}$ En esa localidad además existían un sindicato de fideeros y uno de carpinteros, herreros y anexos ${ }^{81}$. Aunque la debilidad de los sindicatos se expresaba en su aislamiento. La falta de unidad de las fuerzas gremiales era producto de la independencia relativa con la que muchos de estas organizaciones habían nacido. Una misiva entre miembros de la Unión General del Trabajo a obreros de la localidad de Victoria expone este tipo de situaciones:

A la Federación Obrera Victoriense. Estimados compañeros, hemos tenido conocimiento de vuestra federación y de acuerdo a los fines que persigue esta institución nos complacemos en ponernos a vuestra disposición en todo aquello que puede seros útil para la acción y propaganda obrera y su lucha contra del capital. ${ }^{82}$

Otra carta de la Unión General del Trabajo a los obreros panaderos de Concordia, con motivo al pedido de afiliación a la central nacional, decía:

Era ya hora en que entréis a formar parte de la Unión General de Trabajadores, donde se cobijan los que luchan por la acción eminentemente gremial y de base contra de los capitalistas que nos roban el fruto de nuestro trabajo. Compañeros Panaderos, el hombre solo nada puede sin unirse con los demás lo mismo pasas con las sociedades que permanecen aisladas. Nosotros creemos que vosotros comprenderéis las ventajas que os reportaría estar adheridos con los demás compañeros de lucha $[\ldots] .{ }^{83}$

De los intentos de organización que tenemos referencia, el de la Federación Obrera Entrerriana de Paraná fue el más próspero. La Federación estaba afiliada a la F.O.R.A. ${ }^{84}$ Esta Federación Obrera Entrerriana (F.O.E.) no tenía el alcance provincial que su nombre designa,

78 La Fábrica Colón. La Juventud, Concepción del Uruguay, p. 2, 29 mar. 1906; La Huelga en el Saladero Colón. La Juventud, Concepción del Uruguay, p. 1, 24 mar. 1906; Fray Bentos y Colón. La Juventud, Concepción del Uruguay, p. 2, 31 mar. 1906.

79 Lo de la Fábrica Colón. El Entre Ríos, Colón, 5 abr. 1906. Cf.: La Fábrica Colón. La Juventud, Concepción del Uruguay, p. 2, 29 mar. 1906; Huelga General en la Fábrica de Conservas y Extractos Liebig. La Organización Obrera, Buenos Aires, p. 1, 28 dic. 1918; La Huelga en el Saladero Colón. La Juventud, Concepción del Uruguay, 24 mar. 1906; Demostración al jefe de policía. EI Entre Ríos, p. 2, 17 abr. 1906; Otra Huelga etc. La Juventud, Concepción del Uruguay, 21 abr. 1906.

80 Tercer Congreso de la Unión General De Trabajadores. La Acción Socialista, Buenos Aires, p. 3, 21 ago. 1905.

81 UNIÓN GENERAL DE TRABAJADORES. Copiador de Cartas. 09.09.1905-09.01.1906, Hoja 97. UNIÓN GENERAL DE TRABAJADORES. Copiador de Cartas. 09.09.1905-09.01.1906, Hoja 435.

82 FORTANELLI, Juan [Correspondencia] Destinatario: Federación Obrera Victoriense, Buenos Aires, 22 oct.1907, en UNIÓN GENERAL DE TRABAJADORES. Copiador de cartas. 22.10.1906-23.11.1907. Doc. 799.

83 FORTANELLI, Juan [Correspondencia] Destinatario: Sociedad Obreros Panaderos de Concordia, Buenos Aires, Octubre/1907, en UNIÓN GENERAL DE TRABAJADORES. Copiador de cartas. 22.10.1906-23.11.1907. Doc. 876.

84 Abad de Santillán: La FORA... op. cit, p. 202. 
era más bien una alianza local de diversos gremios de Paraná. El programa de la F.O.E. era eminentemente revolucionario, afirmaban: "Toda propiedad adquirida con el trabajo ajeno, constituye un despojo al que lo produjo y por lo tanto toda propiedad individual es un despojo a la colectividad", y proponían la organización racional de la sociedad, en armonía con la naturaleza y la ciencia. Una declaración sin dudas avanzada para la época, pero propia del pensamiento socialista. También proponían una educación integral para niños de ambos sexos que incorpore la práctica en talleres e industrias. Se adelantaba que todas las "Sociedades de resistencia", debían ayudar moral y materialmente a los obreros en huelga, así como cotizar a la Federación en cuestión y a la F.O.R.A. También agregaban en su estatuto: "Declarase el $1^{\circ}$ de Mayo día de alta protesta contra el poder capitalista y las arbitrariedades gubernamentales, absteniéndose los trabajadores de concurrir a su trabajo". ${ }^{85}$

Ahora bien, como fue señalado más atrás, las dificultades y obstáculos no desaparecieron y hacia el fin de nuestro periodo de estudio nos encontramos con las organizaciones obreras desarmadas y con una gran disminución de la conflictividad obrera, posiblemente asociado a la crisis económica ocasionada por la Primera Guerra mundial y a la debilidad de las organizaciones locales, que aún no resistían los embates de la lucha sindical cuando el saldo era negativo para los trabajadores. Prueba del reflujo particular en la provincia es que ninguna organización de Entre Ríos participó del congreso de unificación de $1915{ }^{86}$

\section{Análisis de la acción obrera}

EN EL PRESENTE APARTADO analizaremos brevemente los resultados alcanzados en nuestra investigación sobre la conflictividad obrera entrerriana en el periodo. Metodológicamente, dada la falta de documentación oficial para la provincia, lo que nos hubiera permitido tener una serie completa como pasa en otros periodos de luchas de clases, hemos realizado un esfuerzo importante y reconstruido los datos a partir del repaso de la prensa obrera de la época, de los diarios comerciales locales y documentación de primera mano de las organizaciones obreras. Si bien el trabajo aún está en marcha, la extensión documental y los resultados obtenidos nos permiten un acercamiento al periodo de estudio.

Se ha considerado para este trabajo algunas variables como año, lugar de los conflictos, tipos de acción obrera, gremios implicados y tipo de demanda. No obstante, dado que la construcción se hizo con una diversidad de fuentes, no se pudo completar todas las variables que se pretendían observar para todos los casos. Lo primero que se va a indicar, en el siguiente cuadro, son los tipos de acción obrera.

85 Programa de la Federación Obrera E. Riana. La Ráfaga, Paraná, p. 3-4, 1 dic. 1908.

86 Cf.: MAROTTA, op. cit. T. II., p. 184-185. 
Cuadro 2. Huelgas, boicots y fundaciones de gremios obreros, Entre Ríos, 1901-1916

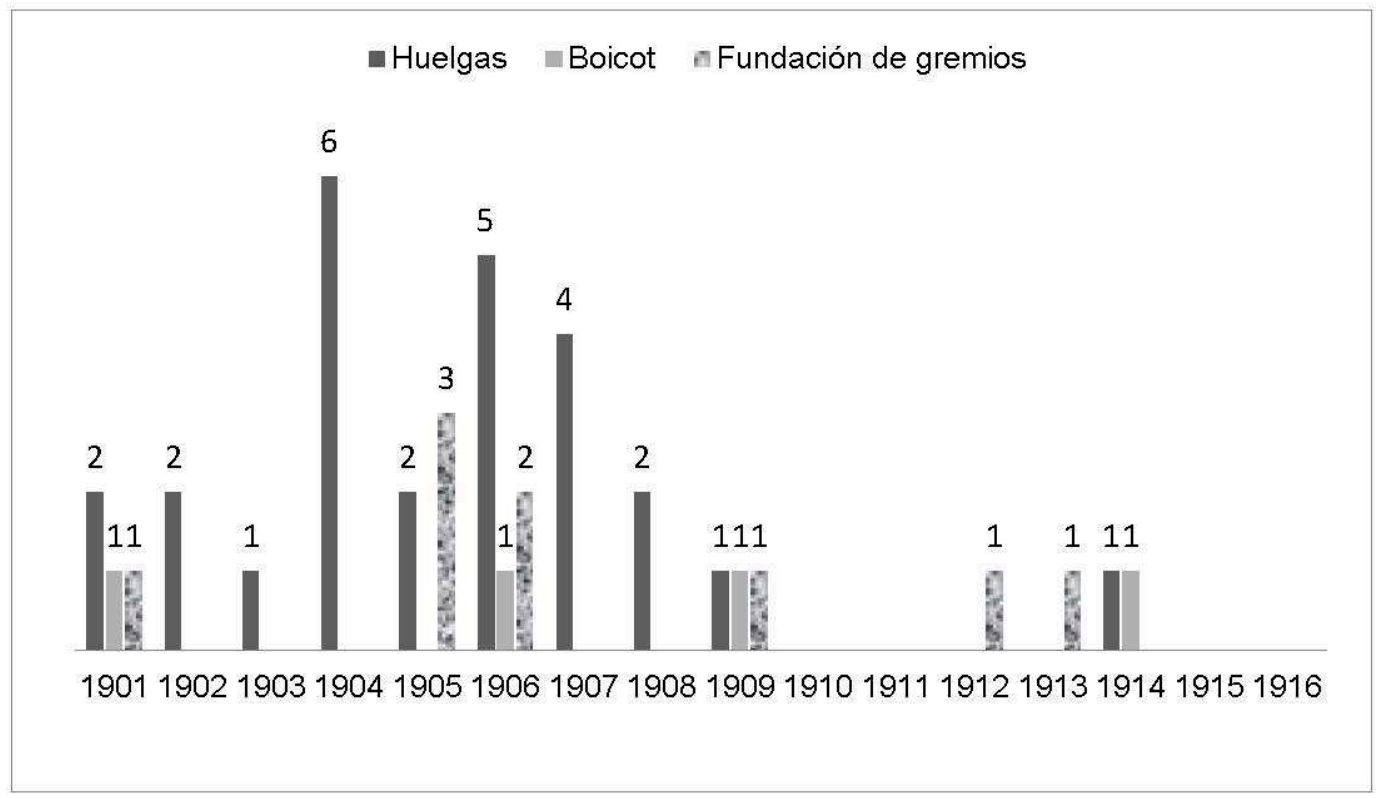

Fuentes: La Vanguardia de Buenos Aires; La Protesta de Buenos Aires; Confederación de Buenos Aires; La Unión Obrera de Buenos Aires; La Organización Obrera de Buenos Aires; La Ráfaga de Paraná, Entre Ríos; El Diamante de Diamante, Entre Ríos; El Argentino de Paraná, Entre Ríos; La Libertad de Paraná, Entre Ríos; El Entre Ríos de Colón, Entre Ríos y La Juventud de Concepción del Uruguay, Entre Ríos. Fuentes inéditas: copiador de actas de la Unión General de Trabajadores de Buenos Aires y las actas de la seccional del Partido Socialista de Concepción del Uruguay.

La serie comienza en 1901 porque, como se indicó, no se han registrado conflictos entre 1895 y el primer año del nuevo siglo y termina con el final de nuestro recorte. En total se han contabilizado 26 huelgas, 4 boicots y 9 fundaciones de gremios. La reconstrucción muestra con claridad que hay una curva de ascenso que comienza en el inicio del siglo XX y alcanza el punto más alto en 1904, cuando se contabilizan 6 huelgas, coincidiendo con el año de mayor conflictividad del resto Argentina. ${ }^{87}$ Luego la curva comienza un descenso tanto en las variables huelgas, organización de gremios y boicots. El final del ciclo es 1909, en consonancia con el comienzo del reflujo de la hegemonía anarquista dentro del movimiento obrero. En el caso particular de Entre Ríos hemos aportado datos sobre las dificultades que los militantes tenían para organizar a los trabajadores. Es decir, no es solo un reflejo.

Los vacíos entre 1910-1916 sólo son interrumpidos por las organizaciones de de los obreros estibadores de Concepción del Uruguay - uno de los gremios más importantes en los siguientes años - en 1912, la creación de la Sociedad Cosmopolita Obrera de Villaguay en 1913, la reconstrucción de un sindicato de oficios varios en Paraná y una huelga de estibadores de Concepción del Uruguay, ambos en $1914 .{ }^{88}$

87 Cf.: KORZENIEWICZ, op. cit

88 Sociedades Gremiales. La Juventud, Concepción del Uruguay, p. 2, 30 mar. 1912; De Villaguay (E. RíOS). La Protesta, Buenos Aires, p. 3, 30 mar. 1913. Paraná. La Protesta, Buenos Aires, p. 3, 11 jul. 1914; PARANÁ. La Protesta, Buenos Aires, p. 3, 14 jul. 1914; La Huelga De Estibadores. La Juventud, Concepción del Uruguay, p. 2, 12 sep. 1914. 
Con respecto a los pedidos en las huelgas, solo hemos encontrado las causas en 18 de las 26 y se concentraban en pedidos económicos, en 13 de ellas se exigía la disminución de la jornada laboral a ocho horas y el aumento de salario. Hubo tres casos de huelgas contra retenciones de salario, atraso en la liquidación de los sueldos y dos pedidos de aumento de las tarifas de los fletes.

Analizando más de cerca las demandas muestran una situación de bajos salarios como el tema central de todas las luchas, mientras el pedido por las ocho horas laborales habla de la situación de sincronía de las luchas locales con las nacionales - cuando no mundiales que pedían por menos horas de trabajo. Mientras tanto, los pedidos contra retenciones o pagos en términos se centralizaban en los obreros abocados al trabajo de obras públicas; espacios laborales en los que intervenía otros actores como los contratistas y el propio estado que retrasaba los pagos al tenor de su situación financiera.

Se han detectado las fracciones obreras de 24 huelgas, dado que las dos huelgas faltantes se indican como huelgas generales (1902 y 1907) y no se discrimina por fracción u oficio. Dentro de las 24 huelgas que se pueden analizar se destacan los panaderos con 4 huelgas, luego albañiles, estibadores y peones de obras públicas generaron 3 huelgas cada fracción, le siguen cocheros y obreros de las canteras con 2 huelgas cada uno y por último, carreros, cigarreros, obreros de la fábrica de fósforos, del frigorífico Liebig, fideeros, herreros y lavanderos con una huelga cada uno. Se reconoce fácilmente, por las fracciones obreras que generaron los conflictos, que se trata del proletariado asociado a los pequeños talleres y manufacturas abocadas al abasto interno de los pueblos, luego las industrias procesadoras de productos de exportación y los trabajadores ocupados en las obras públicas necesarias para el desarrollo capitalista como eran los obreros de los puertos o los trabajadores que se dedicaban a la canalización de riachos. ${ }^{89}$

Llamativamente, en todo este periodo de estudio el proletariado rural estuvo ausente de la lucha de clases de tipo reivindicativo. Un anarquista, Candelario Olivera, se quejaba de que la organización obrera aún no había alcanzado a los obreros rurales, e indicaba la situación de explotación a la que estos trabajadores eran sometidos, con jornadas de más de 14 horas y salarios que él consideraba bajos. ${ }^{90}$ Es posible que el carácter débil de la organización en la ciudad no haya sido suficiente para impulsar a un proletariado aún más disperso territorialmente que el urbano y con un trabajo cíclico alternado por la desocupación. Si bien las fracciones obreras rurales aún están ausentes, serán los actores centrales del próximo ciclo de luchas. ${ }^{91}$

89 Huelga de Peones. La Protesta, Buenos Aires, p. 1, 2 jul. 1904; Paraná. La Protesta, Buenos Aires, p. 3, 30 sep.1904; En Huelga. La Juventud, Concepción del Uruguay, p. 2, 3 ago. 1907.

90 De Diamante a Estación Crespo. La Protesta, Buenos Aires, p. 2, 15 ene. 1908; De Paraná. La Protesta, Buenos Aires, p. 2, 25 ene. 1908.

91 ANSALDI, Waldo; SARTELLI, Eduardo. Una conflictividad débil: los conflictos obreros rurales entrerrianos, 1918-1921. In: ANSALDI, Waldo (comp.). Conflictos obreros rurales pampeanos, 1900-1937. T. II. Buenos Aires: CEAL, 1993. p. 230-250. 
Finalmente, la localización de la huelgas fue en las ciudades portuarias de la provincia. Se destacó Paraná con 11 huelgas, seguido muy detrás por Concepción del Uruguay con 5, Concordia con 3, Gualeguaychú y Gualeguay con 2 huelgas cada localidad; Victoria, Colón y Basavilbaso tuvieron una huelga cada una. Aquí se puede reconocer aquello de que los ríos que delimitan a la provincia de estudio también trazaron la ruta por la cual la organización obrera fue llegando a la provincia.

\section{Conclusiones}

EL PRESENTE ARTículo demostró que la provincia argentina de Entre Ríos comenzó su organización obrera permanente en torno a la década de 1890, aunque existieron registradas manifestaciones de luchas de clases anteriores. La aparente coincidencia con el tempore del resto del proletariado argentino resulta lógica cuando se considera que la provincia en cuestión pertenece a las denominadas provincias pampeanas, es decir, la zona de mayor expansión capitalista de la Argentina y particularmente favorecida por el desarrollo de las fuerzas productivas en las últimas décadas del siglo XIX. Por lo tanto las transformaciones que el sistema capitalista impulsó en esta región generó un proletariado que se incorporó en diversas actividades económicas. Se destacaron las manufacturas y pequeños talleres ocupados en el abasto de mercancías al mercado local, y las actividades enfocadas en la exportación de materias primas; finalmente, los trabajadores ocupados en las obras públicas. Este particular desarrollo social generó una clase trabajadora heterogénea con diversos grados de subordinación al capital y manejo del proceso de trabajo, hecho que redituaba en un lugar estratégico para algunos gremios frente a una masa de obreros desclasificados.

Hemos defendido la hipótesis de que estos trabajadores fueron organizados "desde afuera", es decir, la organización fue obra de otros trabajadores y propagandistas que viajaron al territorio y promovieron la organización, aunque aclaramos que pueden haber existido casos aislados de obreros que lucharon por mejoras de manera autónoma de las grandes organizaciones y que incluso pudieron crear sus propios organismos. Empero, el lugar de estas experiencias deben ser puestas a consideración de la historia general de la clase y merecen un acercamiento particular y pormenorizado.

En tanto en la organización externa se destaca la participación de los socialistas y luego sindicalistas de Buenos Aires, en la costa del río Uruguay y el papel fundamental de los anarquistas de la provincia de Santa Fe en la organización de Paraná. Este impulso organizativo dio resultados espaciados, y si bien ya para los primeros años de 1890 se puede indicar la existencia de núcleos socialistas y anarquistas, será en el cambio de siglo cuando comience un verdadero movimiento obrero local.

Estos grupos de obreros debieron vencer la apatía de los trabajadores, la represión policial y la presión patronal para lograr establecer los gremios. La ciudad capital, Paraná, se 
destacó por encima de todas las localidades por su organización. Sin embargo, a pesar de que el ciclo de conflictos es de poco menos de diez años (1901-1909) los conflictos tuvieron escenario en por lo menos ocho localidades todas, menos Basavilbaso - un cruce de líneas férreas de mucha importancia -, tenían en común ser localidades portuarias, de allí que ganar las costas fue el comienzo del movimiento obrero y desde el cual se fue expandiendo hacia el interior de la provincia.

En conclusión, en este periodo el movimiento obrero reivindicatorio, de la mano de anarquistas y socialistas, logró conquistar las cabezas de playa que sirvieron de base para la siguiente etapa de la organización obrera, pero más importante aún, estableció los lazos con el movimiento obrero del resto de la Argentina.

Recebido em: 13/08/2020

Aprovado em: 19/09/2020 